\title{
Investigation on Field Water Tube and Low Dose Herbicides on Growth Parameters, Microbial Population and Yield of Transplanted Rice (Oryza sativa L.)
}

\author{
R. Mohanapriya* and K. Vijay Aravinth \\ Department of Agronomy, Agricultural College and Research Institute, Killikulam, \\ Thoothukudi, Tamil Nadu \\ *Corresponding author
}

\section{Keywords}

Field water tube, Low dose herbicides, Growth and physiological parameters,

Microbial population, Yield of rice

Article Info

Accepted: 20 December 2020 Available Online: 10 January 2021
A field experiment was conducted at Agricultural College and Research Institute, Killikulam during early Pishanam season of 2018-2019 to investigating suitable irrigation practices through field water tube and weed management practices through low dose herbicides on growth and physiological parameters, microbial population, grain and straw yield of transplanted rice. The experiment was laid out in strip plot design with three replications. The treatments comprised of three different methods of irrigation in vertical strips and four methods of weed management practices in horizontal strips. The experimental results showed that, the growth and physiological parameters like plant height, total tillers $\mathrm{m}^{-2}$, Dry matter production, leaf area index (LAI) and crop growth rate were higher in continuous flooding which is on par with irrigation after $10 \mathrm{~cm}$ depletion field water tube method of irrigation. Among weed management practices, weed free check registered higher growth and physiological parameters and it was comparable with the application of PE Pyrazosulfur on ethyl @ 20g a.i. ha ${ }^{-1} \mathrm{fb}$ POE Bispyribac sodium @ $25 \mathrm{~g}$ a.i. $\mathrm{ha}^{-1}$. Likewise, microbial colonies observation results showed that, higher bacterial and fungal population were found in $10 \mathrm{~cm}$ depletion of field water tube than continuous flooding and actinobacterial colonies were higher in continuous flooding. Among weed management practices, higher fungal and actinobacterial colonies were observed in unweeded control while higher bacterial population were recorded in application of PE Pyrazosulfuron ethyl @ 20g a.i. $\mathrm{ha}^{-1}$ fb POE Bispyribac sodium @ 25g a.i. ha ${ }^{-1}$. The higher grain and straw yield $\left(6882\right.$ and $\left.7675 \mathrm{~kg} \mathrm{ha}^{-1}\right)$ of rice was recorded in continuous submergence coupled with weed free environment. However, field water tube at $10 \mathrm{~cm}$ depletion + application of PE Pyrazosulfuron ethyl @ 20g a.i. ha ${ }^{-1} \mathrm{fb}_{\text {POE }}$ Bispyribac sodium @ $25 \mathrm{~g}$ a.i. ha ${ }^{-1}$ produced the on par yield.

\section{Introduction}

Rice (Oryza sativa L.) is the important staple food crop accounting $44 \%$ of the total food grains and contributes 20 per cent of share in national AGDP. A total of 700-1500 mm of water is required per cropping season to cultivate rice under traditional practices in the tropical and subtropical regions of Asia depending on soil texture and prevailing 
weather. However, a high amount of irrigation water losses through surface runoff, seepage, and percolation accounts to 50-80 per cent of the total water input under traditional rice cultivation practices. There are a number of alternatives to continuous flooding. One approach which can be used is intermittent irrigation or alternate wetting and drying (AWD). Adoption of AWD methods where the irrigation water is applied in the field on an intermittent basis after the disappearance of ponded water instead of continuous flooding. (Zhang et al., 2009).Several studies have shown that AWD is safe method to limit the water use up to $25 \%$ by using of field water tube without reduction in rice yield (Kulkarni 2011) by reducing field level seepage and percolation losses and increase the WUE during the production period.

Rice is cultivated in different ecosystems and weeds are the most important menace to cause low productivity of rice depending upon the different establishment methods. Weeds are highly competitive for moisture, nutrients, light, temperature and space with rice. Furthermore, the negative correlation may occur with crop yield for any delay in weeding. Good control of weed can be attained by employing proper water management practices (Bhan 1981) while maintaining the water regimes under field capacity encourages weed growth (Smith and Fox 1973). Weed composition are mostly altered by the changing water regimes and soil moisture status (Janiya and Moody 1982). Good start and competitive superiority of the crop is obtained through proper herbicides which offers selective and economic control of weeds right from the beginning. In present day agriculture, herbicides like bensulfuron methyl, pyrazosulfuron ethyl and bispyribac sodium are the most commonly used in rice (Saha and Rao 2009) which are highly effective at low rate of application and to control broad spectrum of weeds and annual sedges.

\section{Materials and Methods}

The field experiment was conducted during early Pishanam season of 2018-2019 at the BC Block Farm, Agricultural College and Research Institute, Killikulam, Tamil Nadu. The farm is geographically located in the southern part of Tamil Nadu at $8^{\circ} 46^{\prime} \mathrm{N}$ latitude and $77^{\circ} 42^{\prime}$ E longitude at an altitude of $40 \mathrm{~m}$ above mean sea level. The soil of the experimental site was sandy clay loam in texture having alkaline $\mathrm{pH}$ (8.2) and medium organic carbon $\left(6.2 \mathrm{~g} \mathrm{~kg}^{-1}\right)$. The soil was low in available nitrogen $\left(244 \mathrm{~kg} \mathrm{ha}^{-1}\right)$, medium in phosphorus (22 $\mathrm{kg} \mathrm{ha} \mathrm{ha}^{-1}$ and medium in potassium (238 $\mathrm{kg} \mathrm{ha}^{-1}$ ), respectively. Rice variety ASD 16 with the duration of 110 days was used as test variety. Field experiments were laid out in strip plot design with three replications. The treatments comprised of three different methods of irrigation viz., Irrigation after $10 \mathrm{~cm}$ depletion of Field Water Tube (FWT) (from surface level) from 10 DAT to 10 days prior to harvest $\left(\mathrm{A}_{1}\right)$, Irrigation after $15 \mathrm{~cm}$ depletion of Field Water Tube FWT (from surface level) up to maximum tillering stage (30-35 DAT) and 10 $\mathrm{cm}$ depletion of FWT to 10 days prior to harvest $\left(\mathrm{A}_{2}\right)$, Continuous Submergence (farmers practice) $\left(\mathrm{A}_{3}\right)$, respectively in vertical strips and four methods of weed management practices in horizontal strips viz., PE Bensulfuron methyl + Pretilachlor @ 0.6 $\mathrm{kg}$ a.i. ha ${ }^{-1}$ fb POE Bispyribac sodium @ 25g a.i. ha ${ }^{-1}\left(B_{1}\right)$, PE Pyrazosulfuron ethyl @ 20g a.i. ha ${ }^{-1}$ fb POE Bispyribac sodium @ $25 \mathrm{~g}$ a.i.ha ${ }^{-1}\left(\mathrm{~B}_{2}\right)$, Weed free check $\left(\mathrm{B}_{3}\right)$, Un weeded control $\left(\mathrm{B}_{4}\right)$. Growth parameters viz.,plant height, total tillers $\mathrm{m}^{-2}$, dry matter production and physiological parameters viz., leaf area index, crop growth rate and yield were recorded and interpreted here under. Microbial population viz., bacteria, fungi and 
actinobacteria in soil were recorded using standard growth medias and discussed here.

\section{Results and Discussion}

\section{Growth parameters}

\section{Plant height (Table 1)}

Plant height is an indicator of growth performance of a crop, as influenced by environment and management factors. The height of plant was increased with the progression of crop growth from AT stage and it reached maximum at harvest stage. Significant effect was found on the plant height due to various irrigation management at all the stages of crop growth. Continuous flooding $\left(\mathrm{A}_{3}\right)$ produced significantly taller plants $(58.1,86.6$ and $102.3 \mathrm{~cm})$ at AT, PI and at harvest and on par with $10 \mathrm{~cm}$ depletion of Field Water Tube $\left(\mathrm{A}_{1}\right)$ produced $56.1, \quad 85.2$ and $100.2 \mathrm{~cm}$, respectively. Meristematic cells activity and internodes cell elongation stimulated by continuous flooding resulted in higher stem growth rate and in turn promoting the rice height (Chowdhury et al., 2014). The similar result with higher plant height was obtained in continuous submergence treatment than other AWD treatments were reported by Oliver et al., (2008). Irrigation at $15 \mathrm{~cm}$ depletion of Field Water Tube $\left(\mathrm{A}_{2}\right)$ resulted in shorter plant height of 52.3, 79.0 and $92.2 \mathrm{~cm}$ at all growth stages. Any depletion of soil moisture faced by rice at any growth stage before anthesis significantly reduced the plant height reported by Santheepan and Ramanathan (2016) and Oliver et al., (2008).

Imposing of different weed control, the height of plant was maximum in weed free check $\left(\mathrm{B}_{3}\right)$ produced $60,89.5$ and $108.9 \mathrm{~cm}$ of plant height at AT, PI and harvest, respectively. It was statistically parallel among PE Pyrazosulfuron ethyl @ 20g a.i. ha ${ }^{-1}$ fb POE
Bispyribac sodium @ 25 g a.i. ha ${ }^{-1}\left(\mathrm{~B}_{2}\right)$ gave $58.7,88.0$ and $105.9 \mathrm{~cm}$, respectively at three stages. This could be attributed to the herbicidal combination control the weed better resulting in enhanced nutrient depletion by the crop reflected on height. The results are in line with Shekhar et al., (2004). Unweeded control $\left(\mathrm{B}_{4}\right)$ exhibited significantly lowest plant height of $49.3,75.0$ and $79.0 \mathrm{~cm}$ at three phases of observations. The interactions were recorded as non-significant during AT, PI and at harvest.

\section{Total tillers $\mathrm{m}^{-2}$ (Table 2)}

In general, during the beginning tiller production starts slowly, attains to its peak at active vegetative and then started to decline as the age of the crop proceed. Continuous flooding $\left(\mathrm{A}_{3}\right)$ produces considerably a greater tillers $\mathrm{m}^{-2}$ at AT, PI and harvest $(255,313$ and 336 , respectively).It was governed by better aeration resulted in favourable root growth and more absorption of nutrients as observed from increased uptake of nutrients consequently resulted in more growth and tiller production. It was statistically comparable with irrigation after $10 \mathrm{~cm}$ depletion of FWT $\left(\mathrm{A}_{1}\right)$ registering 252, 308 and 332 tillers $\mathrm{m}^{-2}$. Similar result of irrigating the field when water table in the porous tube at $10 \mathrm{~cm}$ depletion recorded maximum number of total tillers has been stated by Subramanian et al., (2002).Whereas, the least tillers $\mathrm{m}^{-2}$ was obtained with adoption of 15 $\mathrm{cm}$ depletion of FWT $\left(\mathrm{A}_{2}\right)$ at all the crop growth stages $\left(227,287\right.$ and 308 tillers $\mathrm{m}^{-2}$, respectively).

All the weed management treatments showed distinct superiority over unweeded control in total number of tillers $\mathrm{m}^{-2}$. Weed free check $\left(B_{3}\right)$ produced reasonable number of tillers of 282, 338 and $361 \mathrm{~m}^{-2}$, respectively. This result was also corroborated with Patra et al., (2011). It exhibited statistically similar values 
with the application of PE Pyrazosulfuron ethyl @20g a.i. ha ${ }^{-1}$ fb POE Bispyribac sodium @ $25 \mathrm{~g}$ a.i. $\mathrm{ha}^{-1}$ (B2) registering 273, 328 and 355 tillers $\mathrm{m}^{-2}$ at all the three stages. Reduced weed competition at early stage of rice improved the growth structure such as tiller production. This is in consistence with findings of Singh et al., (2016). Invariably, least number of total tillers $(165,236$ and 252 $\mathrm{m}^{-2)}$ was recorded in unweeded control (B4) at all stages.

Combination of various irrigation and weed control had substantial interaction with each other on tillers $\mathrm{m}^{-2}$ at AT, PI and harvest stages. Continuous flooding with weed free check $\left(\mathrm{A}_{3} \mathrm{~B}_{3}\right)$ produced maximum number of tillers (299, 349 and 375, respectively). However, it was statistically identical with irrigation after $10 \mathrm{~cm}$ depletion of FWT together with weed free check $\left(\mathrm{A}_{1} \mathrm{~B}_{3}\right)$ registered more tillers $\left(295,345\right.$ and $\left.368 \mathrm{~m}^{-2}\right)$. It was governed by lesser weed population and better aeration resulted in favourable root growth and more absorption of nutrients as observed from increased uptake of nutrients consequently resulted in more growth and tiller production. Similar result has been stated by Kunnathadi et al., (2015).

\section{Dry matter accumulation (Table 3)}

Generally, plant dry matter increased as the stage of crop progressed to harvest and attained the maximum level at harvest. Continuous flooding $\left(\mathrm{A}_{3}\right)$ produced higher DMP registered at AT, PI and at harvest (2284, 7896 and $12796 \mathrm{~kg} \mathrm{ha}^{-1}$, respectively). Whereas, it was comparable with $10 \mathrm{~cm}$ depletion of FWT $\left(A_{1}\right)$ registering 2193, 7550 and $12231 \mathrm{~kg} \mathrm{ha}^{-1}$, respectively. The increase in DMP of rice with AWD might have brought up by loose soil, which facilitates more access to water and nutrients by roots. The correlated outcome of the results was observed by Maragatham and Martin
(2010).The lesser DMP was noticed in $15 \mathrm{~cm}$ depletion of FWT $\left(\mathrm{A}_{2}\right)$ at all the three stages (1946, 6752 and $11026 \mathrm{~kg} \mathrm{ha} \mathrm{h}^{-1}$, respectively).The same results are in concurrence with Kabir et al., (2008).

Weed free check (B3) recorded significantly higher DMP of 2361, 8717 and $14431 \mathrm{~kg} \mathrm{ha}^{-1}$. It was identical with PE Pyrazosulfuron ethyl @ 20g a.i. $\mathrm{ha}^{-1} \mathrm{fb}$ POEBispyribac sodium @ $25 \mathrm{~g}$ a.i. $\mathrm{ha}^{-1}$ (B2) with a DMP of 2351,8422 and $13900 \mathrm{~kg} \mathrm{ha}^{-1}$, respectively. This is in consistent with the conclusion of Walia et al., (2012). The higher DMP found in the above treatment might be due to the lesser competition by weeds as it might have been killed from their germination phase and keeping weeds at lower densities. The lowest DMP was computed in unweeded control plot, which registered a DMP of 1643, 4889 and $7122 \mathrm{~kg} \mathrm{ha}^{-1}$ at AT, PI and at harvest.

Significant interaction effect was noticed at three stages of crop. At AT stage, more amount of DMP was recorded in continuous submergence with PE Pyrazosulfuron ethyl @ $20 \mathrm{~g}$ a.i. ha $^{-1} \mathrm{fb}$ POE Bispyribac sodium @ $25 \mathrm{~g}$ a.i. $\mathrm{ha}^{-1}$ with a DMP of $2519 \mathrm{~kg} \mathrm{ha}^{-1}$. It was comparable with irrigation after $10 \mathrm{~cm}$ depletion of FWT with weed free check $\left(\mathrm{A}_{1} \mathrm{~B}_{3}\right)$ and continuous submergence with weed free check $\left(\mathrm{A}_{3} \mathrm{~B}_{3}\right)$. At PI and harvest, higher DMP was noticed in continuous submergence with weed free check $\left(\mathrm{A}_{3} \mathrm{~B}_{3}\right)$ recorded 9389 and $15594 \mathrm{~kg} \mathrm{ha}^{-1}$, respectively and it was parallel with continuous submergence with the application of PE Pyrazosulfuron ethyl @ 20g a.i. ha ${ }^{-1} \mathrm{fb}$ POE Bispyribac sodium @ $25 \mathrm{~g}$ a.i. ha $^{-1}\left(\mathrm{~A}_{3} \mathrm{~B}_{2}\right)$ registered the DMP of 8925 and $14592 \mathrm{~kg} \mathrm{ha}^{-1}$, correspondingly and the lower DMP was produced in Irrigation after $15 \mathrm{~cm}$ depletion of FWT with unweeded control treatment $\left(\mathrm{A}_{2} \mathrm{~B}_{4}\right)$ recorded 4307 and $6358 \mathrm{~kg}$ $\mathrm{ha}^{-1}$. 
Table.1 Effect of different irrigation and weed management practices on rice plant height $(\mathrm{cm})$

\begin{tabular}{|c|c|c|c|c|c|c|c|c|c|c|c|c|c|c|c|c|c|}
\hline \multirow[t]{2}{*}{ Treatment } & \multicolumn{5}{|c|}{ Active tillering } & & \multicolumn{5}{|c|}{ Panicle initiation } & & \multicolumn{5}{|c|}{ At harvest } \\
\hline & $\mathrm{B}_{1}$ & $\mathrm{~B}_{2}$ & $\mathrm{~B}_{3}$ & $\mathrm{~B}_{4}$ & Mean & & $\mathrm{B}_{1}$ & $\mathrm{~B}_{2}$ & $\mathrm{~B}_{3}$ & $\mathrm{~B}_{4}$ & Mean & & $\mathrm{B}_{1}$ & $\mathrm{~B}_{2}$ & $\mathrm{~B}_{3}$ & $\mathrm{~B}_{4}$ & Mean \\
\hline $\mathbf{A}_{1}$ & 54.5 & 58.7 & 61.5 & 49.8 & 56.1 & $\mathrm{~A}_{1}$ & 83.2 & 90.2 & 90.1 & 77.2 & 85.2 & $\mathrm{~A}_{1}$ & 99.4 & 108.6 & 111.5 & 81.2 & 100.2 \\
\hline $\mathbf{A}_{2}$ & 51.2 & 57.1 & 55.3 & 45.7 & 52.3 & $\mathrm{~A}_{2}$ & 77.1 & 83.5 & 85.7 & 69.6 & 79.0 & $\mathrm{~A}_{2}$ & 93.5 & 98.6 & 101.5 & 75.2 & 92.2 \\
\hline $\mathbf{A}_{3}$ & 59.3 & 60.3 & 63.3 & 52.3 & 58.1 & $\mathrm{~A}_{3}$ & 85.6 & 90.2 & 92.6 & 78.1 & 86.6 & $\mathrm{~A}_{3}$ & 104.6 & 110.5 & 113.6 & 80.5 & 102.3 \\
\hline Mean & 54.0 & 58.7 & 60.0 & 49.3 & & & 82.0 & 88.0 & 89.5 & 75.0 & & & 99.2 & 105.9 & 108.9 & 79.0 & \\
\hline & A & B & $\mathrm{A}$ at $\mathrm{B}$ & B at A & & & A & B & $A$ at $B$ & $\mathrm{~B}$ at $\mathrm{A}$ & & & A & B & $A$ at $B$ & B at A & \\
\hline SEd & 1.8 & 1.7 & 2.3 & 2.1 & & & 2.8 & 2.7 & 6.1 & 5.7 & & & 3.2 & 3.0 & 7.5 & 6.9 & \\
\hline
\end{tabular}

Table.2 Effect of different irrigation and weed management practices on total tillers $\mathrm{m}^{-2}$

\begin{tabular}{|c|c|c|c|c|c|c|c|c|c|c|c|c|c|c|c|c|c|}
\hline \multirow[t]{2}{*}{ Treatment } & \multicolumn{5}{|c|}{ Active tillering } & & \multicolumn{5}{|c|}{ Panicle initiation } & & \multicolumn{5}{|c|}{ At harvest } \\
\hline & $\mathrm{B}_{1}$ & $\mathrm{~B}_{2}$ & $\mathrm{~B}_{3}$ & $\mathrm{~B}_{4}$ & Mean & & $\mathrm{B}_{1}$ & $\mathrm{~B}_{2}$ & $\mathrm{~B}_{3}$ & $\mathrm{~B}_{4}$ & Mean & & $\mathrm{B}_{1}$ & $\mathrm{~B}_{2}$ & $\mathrm{~B}_{3}$ & $\mathrm{~B}_{4}$ & Mean \\
\hline $\mathbf{A}_{1}$ & 263 & 283 & 295 & 165 & 252 & $\mathrm{~A}_{1}$ & 313 & 333 & 345 & 240 & 308 & $\mathrm{~A}_{1}$ & 335 & 365 & 368 & 261 & 332 \\
\hline $\mathbf{A}_{2}$ & 242 & 250 & 253 & 161 & 227 & $\mathrm{~A}_{2}$ & 292 & 315 & 320 & 221 & 287 & $\mathrm{~A}_{2}$ & 325 & 338 & 340 & 230 & 308 \\
\hline $\mathbf{A}_{3}$ & 265 & 285 & 299 & 169 & 255 & $\mathrm{~A}_{3}$ & 320 & 335 & 349 & 247 & 313 & $\mathrm{~A}_{3}$ & 340 & 363 & 375 & 265 & 336 \\
\hline \multirow[t]{2}{*}{ Mean } & 257 & 273 & 282 & 165 & & & 308 & 328 & 338 & 236 & & & 333 & 355 & 361 & 252 & \\
\hline & A & B & $A$ at $B$ & B at A & & & A & B & $A$ at B & B at A & & & A & B & $A$ at B & $\mathrm{B}$ at $\mathrm{A}$ & \\
\hline SEd & 8.4 & 8.0 & 9.6 & 8.2 & & & 8.6 & 7.1 & 9.9 & 9.1 & & & 10.4 & 9.9 & 11.6 & 10.5 & \\
\hline
\end{tabular}

Table.3 Effect of different irrigation and weed management practices on dry matter production $\left(\mathrm{kg} \mathrm{ha}^{-1}\right)$

\begin{tabular}{|c|c|c|c|c|c|c|c|c|c|c|c|c|c|c|c|c|c|}
\hline \multirow[t]{2}{*}{ Treatment } & \multicolumn{5}{|c|}{ Active tillering } & & \multicolumn{5}{|c|}{ Panicle initiation } & & \multicolumn{5}{|c|}{ At harvest } \\
\hline & $\mathrm{B}_{1}$ & $\mathrm{~B}_{2}$ & $\mathrm{~B}_{3}$ & $\mathrm{~B}_{4}$ & Mean & & $\mathrm{B}_{1}$ & $\mathrm{~B}_{2}$ & $\mathrm{~B}_{3}$ & $\mathrm{~B}_{4}$ & Mean & & $\mathrm{B}_{1}$ & $\mathrm{~B}_{2}$ & $\mathrm{~B}_{3}$ & $\mathrm{~B}_{4}$ & Mean \\
\hline $\mathbf{A}_{1}$ & 2280 & 2363 & 2462 & 1668 & 2193 & $\mathrm{~A}_{1}$ & 7786 & 8497 & 8805 & 5110 & 7550 & $\mathrm{~A}_{1}$ & 12877 & 14077 & 14540 & 7428 & 12231 \\
\hline $\mathbf{A}_{2}$ & 1962 & 2170 & 2191 & 1462 & 1946 & $\mathrm{~A}_{2}$ & 6899 & 7845 & 7957 & 4307 & 6752 & $\mathrm{~A}_{2}$ & 11557 & 13030 & 13158 & 6358 & 11026 \\
\hline $\mathbf{A}_{3}$ & 2389 & 2519 & 2430 & 1798 & 2284 & $\mathrm{~A}_{3}$ & 8019 & 8925 & 9389 & 5250 & 7896 & $\mathrm{~A}_{3}$ & 13310 & 14592 & 15594 & 7580 & 12769 \\
\hline Mean & 2210 & 2351 & 2361 & 1643 & & & 7568 & 8422 & 8717 & 4889 & & & 12581 & 13900 & 14431 & 7122 & \\
\hline & A & B & $A$ at $B$ & B at A & & & A & B & $A$ at $B$ & B at A & & & A & B & $A$ at $B$ & $\mathrm{~B}$ at $\mathrm{A}$ & \\
\hline SEd & 105.3 & 101.5 & 108.5 & 90.1 & & & 314.5 & 275.2 & 304.0 & 281.4 & & & 455.4 & 437.2 & 475.9 & 449.6 & \\
\hline
\end{tabular}


Table.4 Effect of different irrigation and weed management practices on leaf area index

\begin{tabular}{|c|c|c|c|c|c|c|c|c|c|c|c|}
\hline \multirow[t]{2}{*}{ Treatment } & \multicolumn{5}{|c|}{ Active tillering } & & \multicolumn{5}{|c|}{ Panicle initiation } \\
\hline & $\mathrm{B}_{1}$ & $\mathrm{~B}_{2}$ & $\mathrm{~B}_{3}$ & $\mathrm{~B}_{4}$ & Mean & & $\mathrm{B}_{1}$ & $\mathrm{~B}_{2}$ & $\mathrm{~B}_{3}$ & $\mathrm{~B}_{4}$ & Mean \\
\hline $\mathbf{A}_{1}$ & 2.71 & 3.67 & 4.05 & 2.26 & 56.1 & $\mathrm{~A}_{1}$ & 3.54 & 4.83 & 5.39 & 2.66 & 4.11 \\
\hline $\mathbf{A}_{2}$ & 2.63 & 3.19 & 3.24 & 2.20 & 52.3 & $\mathrm{~A}_{2}$ & 3.22 & 4.58 & 4.22 & 2.63 & 3.66 \\
\hline $\mathbf{A}$ & 2.74 & 3.91 & 4.08 & 2.31 & 58.1 & $\mathrm{~A}_{3}$ & 4.95 & 4.91 & 5.49 & 2.76 & 4.53 \\
\hline Mean & 2.69 & 3.59 & 3.79 & 2.26 & & & 3.90 & 4.77 & 5.03 & 2.68 & \\
\hline & A & B & $A$ at $B$ & B at A & & & A & B & $\mathrm{A}$ at $\mathrm{B}$ & B at $\mathrm{A}$ & \\
\hline SEd & 0.09 & 0.09 & 0.12 & 0.12 & & & 0.12 & 0.12 & 0.25 & 0.26 & \\
\hline $\operatorname{CD}(p=0.05)$ & 0.20 & 0.21 & NS & NS & & & 0.26 & 0.27 & $\mathrm{NS}$ & NS & \\
\hline
\end{tabular}

Table.5 Effect of different irrigation and weed management practices on crop growth rate $\left(\mathrm{kg} \mathrm{ha}^{-1} \mathrm{day}^{-1}\right)$

\begin{tabular}{|c|c|c|c|c|c|c|c|c|c|c|c|}
\hline \multirow[t]{2}{*}{ Treatment } & \multicolumn{5}{|c|}{ Active tillering - Panicle initiation } & & \multicolumn{5}{|c|}{ Panicle initiation - at harvest } \\
\hline & $\mathrm{B}_{1}$ & $\mathrm{~B}_{2}$ & $\mathrm{~B}_{3}$ & $\mathrm{~B}_{4}$ & Mean & & $\mathrm{B}_{1}$ & $\mathrm{~B}_{2}$ & $\mathrm{~B}_{3}$ & $\mathrm{~B}_{4}$ & Mean \\
\hline $\mathbf{A}_{1}$ & 183.5 & 204.5 & 211.4 & 114.7 & 178.5 & $\mathrm{~A}_{1}$ & 169.7 & 186.0 & 191.2 & 77.3 & 156.1 \\
\hline $\mathbf{A}_{2}$ & 164.6 & 189.2 & 192.2 & 94.8 & 160.2 & $\mathrm{~A}_{2}$ & 155.3 & 172.8 & 173.4 & 68.4 & 142.5 \\
\hline $\mathbf{A}$ & 187.7 & 213.5 & 232.0 & 115.1 & 187.1 & $\mathrm{~A}_{3}$ & 176.4 & 188.9 & 206.8 & 77.7 & 162.5 \\
\hline Mean & 178.6 & 202.4 & 211.9 & 108.2 & & & 167.1 & 182.6 & 190.5 & 74.5 & \\
\hline & A & B & $A$ at $B$ & $\mathrm{~B}$ at $\mathrm{A}$ & & & A & B & $A$ at $B$ & $\mathrm{~B}$ at $\mathrm{A}$ & \\
\hline SEd & 5.6 & 5.2 & 5.7 & 4.5 & & & 4.9 & 4.3 & 10.7 & 9.8 & \\
\hline $\mathrm{CD}(\mathrm{p}=0.05)$ & 12.1 & 11.2 & 12.2 & 10.9 & & & 10.7 & 9.3 & NS & NS & \\
\hline
\end{tabular}

Table.6 Effect of different irrigation and weed management practices on microbial population soil (cfu g ${ }^{-1}$ )

\begin{tabular}{|c|c|c|c|c|c|c|c|c|c|c|c|c|c|c|c|c|c|}
\hline \multirow[t]{2}{*}{ Treatment } & \multicolumn{5}{|c|}{ Bacteria $\left(10^{6} \mathrm{cfu} \mathrm{g}^{-1}\right)$} & & \multicolumn{5}{|c|}{ Fungi $\left(10^{6} \mathrm{cfu} \mathrm{g}^{-1}\right)$} & & \multicolumn{5}{|c|}{ Actinobacteria $\left(10^{6} \mathrm{cfu} \mathrm{g}^{-1}\right)$} \\
\hline & $\mathrm{B}_{1}$ & $\mathrm{~B}_{2}$ & $\mathrm{~B}_{3}$ & $\mathrm{~B}_{4}$ & Mean & & $\mathrm{B}_{1}$ & $\mathrm{~B}_{2}$ & $\mathrm{~B}_{3}$ & $\mathrm{~B}_{4}$ & Mean & & $\mathrm{B}_{1}$ & $\mathrm{~B}_{2}$ & $\mathrm{~B}_{3}$ & $\mathrm{~B}_{4}$ & Mean \\
\hline $\mathbf{A}_{1}$ & $13 \times 10^{6}$ & $15 \times 10^{6}$ & $10 \times 10^{6}$ & $12 \times 10^{6}$ & $13 \times 10^{6}$ & $\mathrm{~A}_{1}$ & $6 \times 10^{3}$ & $8 \times 10^{3}$ & $4 \times 10^{3}$ & $9 \times 10^{3}$ & $7 \times 10^{3}$ & $\mathrm{~A}_{1}$ & $3 \times 10^{2}$ & $4 \times 10^{2}$ & $2 \times 10^{2}$ & $8 \times 10^{2}$ & $4 \times 10^{2}$ \\
\hline $\mathbf{A}_{2}$ & $12 \times 10^{5}$ & $14 \times 10^{5}$ & $9 \times 10^{5}$ & $11 \times 10^{5}$ & $12 \times 10^{5}$ & $\mathrm{~A}_{2}$ & $5 \times 10^{3}$ & $6 \times 10^{3}$ & $3 \times 10^{3}$ & $7 \times 10^{3}$ & $5 \times 10^{3}$ & $\mathrm{~A}_{2}$ & $5 \times 10^{2}$ & $6 \times 10^{2}$ & $2 \times 10^{2}$ & $7 \times 10^{2}$ & $5 \times 10^{2}$ \\
\hline $\mathbf{A}_{3}$ & $7 \times 10^{4}$ & $7 \times 10^{4}$ & $4 \times 10^{4}$ & $5 \times 10^{4}$ & $6 \times 10^{4}$ & $\mathrm{~A}_{3}$ & $3 \times 10^{2}$ & $4 \times 10^{2}$ & $2 \times 10^{2}$ & $5 \times 10^{2}$ & $4 \times 10^{2}$ & $\mathrm{~A}_{3}$ & $6 \times 10^{1}$ & $8 \times 10^{1}$ & $3 \times 10^{1}$ & $9 \times 10^{1}$ & $7 \times 10^{1}$ \\
\hline Mean & $11 \times 10^{5}$ & $12 \times 10^{6}$ & $8 \times 10^{5}$ & $9 \times 10^{6}$ & & & $5 \times 10^{3}$ & $6 \times 10^{3}$ & $3 \times 10^{2}$ & $7 \times 10^{3}$ & & & $5 \times 10^{2}$ & $6 \times 10^{2}$ & $2 \times 10^{2}$ & $8 \times 10^{2}$ & \\
\hline
\end{tabular}

*Data not statistically analyzed 
Table.7 Effect of different irrigation and weed management practices on grain and straw yield $\left(\mathrm{kg} \mathrm{ha}^{-1}\right)$ of transplanted rice

\begin{tabular}{|c|c|c|c|c|c|c|c|c|c|c|c|}
\hline \multirow[t]{2}{*}{ Treatment } & \multicolumn{5}{|c|}{ Grain yield (kg ha $\left.{ }^{-1}\right)$} & & \multicolumn{5}{|c|}{ Straw yield $\left(\mathrm{kg} \mathrm{ha}^{-1}\right)$} \\
\hline & $\mathrm{B}_{1}$ & $\mathrm{~B}_{2}$ & $\mathrm{~B}_{3}$ & $\mathrm{~B}_{4}$ & Mean & & $\mathrm{B}_{1}$ & $\mathrm{~B}_{2}$ & $\mathrm{~B}_{3}$ & $\mathrm{~B}_{4}$ & Mean \\
\hline $\mathbf{A}_{1}$ & 6245 & 6720 & 6880 & 3558 & 5851 & $\mathrm{~A}_{1}$ & 7110 & 7553 & 7969 & 5110 & 7550 \\
\hline $\mathbf{A}_{2}$ & 5210 & 5995 & 6520 & 2968 & 5173 & $\mathrm{~A}_{2}$ & 6054 & 6920 & 7957 & 4307 & 6752 \\
\hline $\mathbf{A}_{3}$ & 6412 & 6720 & 6859 & 4898 & 6222 & $\mathrm{~A}_{3}$ & 7306 & 7678 & 9389 & 5250 & 7896 \\
\hline Mean & 5956 & 6478 & 6753 & 3808 & & & 6823 & 7384 & 8717 & 4889 & \\
\hline & A & B & $A$ at $B$ & $\mathrm{~B}$ at $\mathrm{A}$ & & & A & B & $A$ at $B$ & $\mathrm{~B}$ at $\mathrm{A}$ & \\
\hline SEd & 256.8 & 235.7 & 249.6 & 235.3 & & & 305.4 & 289.5 & 304.0 & 281.4 & \\
\hline$C D(p=0.05)$ & 557.3 & 511.4 & 541.6 & 510.6 & & & 662.8 & 628.2 & 659.8 & 610.7 & \\
\hline
\end{tabular}

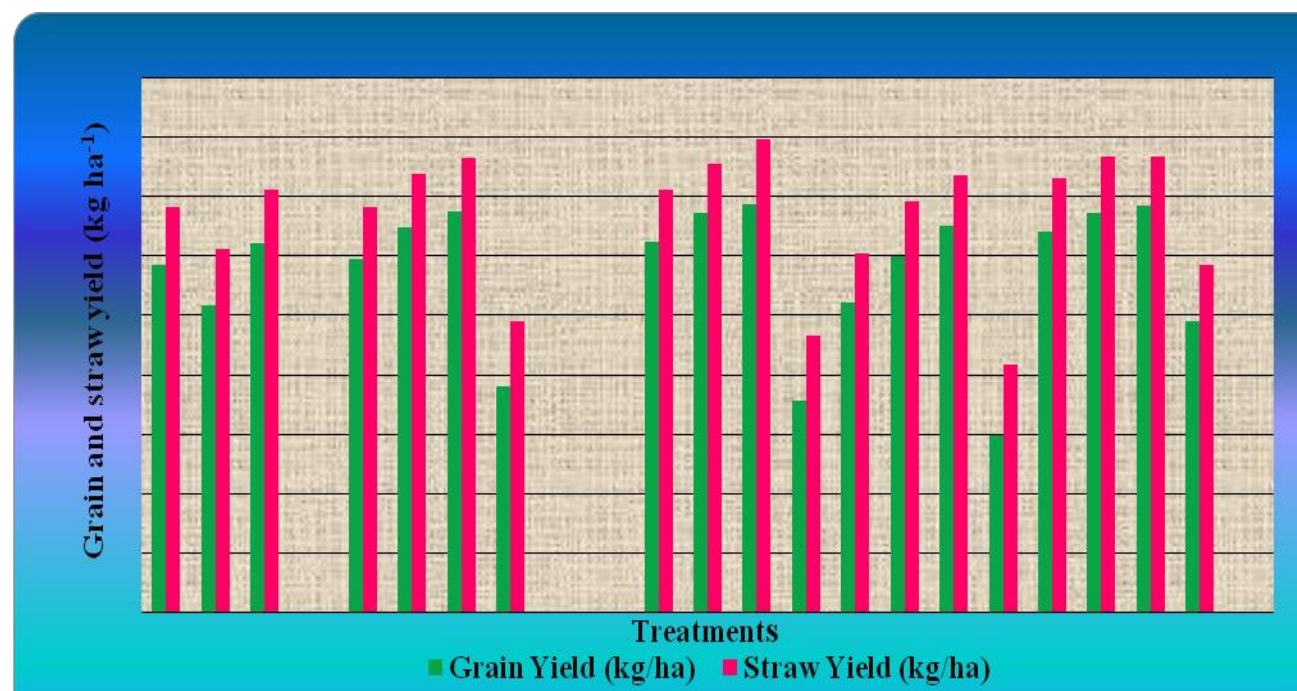

Fig.1. Different irrigation regimes and weed management practices on grain and straw yield $\left(\mathrm{kg} \mathrm{ha}^{-1}\right)$ 


\section{Physiological parameters}

\section{Leaf area index (Table 4)}

Measurement of leaf area and assessment of LAI are the basic tools for growth analysis. The LAI varied appreciably in a predictable manner with the plant height as one of the factors for calculation. Among the different irrigation management practices, largest plant canopy was registered with continuous submergence $\left(\mathrm{A}_{3}\right)$ recorded LAI of 3.26 and 4.53 , respectively. The increased LAI might have been brought up by favourable moisture regimes and more soil nutrient uptake, belated senescence of the leaves with higher photosynthetic rate which resulted in better LAI reported by Thakur et al., (2010).The next largest plant canopy was found in irrigation after $10 \mathrm{~cm}$ depletion of FWT $\left(\mathrm{A}_{1}\right)$ with a LAI of 3.17 and 4.11. The above two treatments are statistically comparable with each other. Water stress affects photosynthetic rate $(\mathrm{Pn})$ which supports to a reduction of photosynthetic rate in plants grown under AWD conditions but saturated or above water condition did not affect photosynthetic rate, transpiration rate. This is agreed with the conclusion of Okuma et al., (2011). This was followed by irrigation after $15 \mathrm{~cm}$ depletion of FWT $\left(\mathrm{A}_{2}\right)$ recorded LAI of 2.82 and 3.66 at AT and PI stages.

Significantly higher LAI values of 3.79 and 5.03 at AT and PI, respectively was noted with weed free check $\left(A_{3}\right)$. It was statistically identical with PE Pyrazosulfuron ethyl @ 20g a.i. ha ${ }^{-1} \mathrm{fb}$ POE Bispyribac sodium @ $25 \mathrm{~g}$ a.i. $\mathrm{ha}^{-1}$ evidenced 3.59 and 4.77 , respectively. This is as a result of better control of weeds which reduce the competition for growth component of rice. (Satyanarayana Reddy et al., 2013)made related conclusions. Lowest LAI of 2.26 and 2.68 at AT and PI stages was recorded in unweeded control $\left(\mathrm{A}_{4}\right)$.
Irrigation and weed management practices had substantial interaction with each other at panicle initiation stage. Higher LAI was recorded in continuous flooding with weed free check $\left(\mathrm{A}_{3} \mathrm{~B}_{3}\right)$, which was identical with irrigation after $10 \mathrm{~cm}$ depletion of FWT with weed free check $\left(\mathrm{A}_{1} \mathrm{~B}_{3}\right)$ produced largest plant canopy of 5.49 and 5.39, respectively at panicle initiation stage. The proper soil aeration maintained under water saving irrigation facilitated production of more tillers number and consequently higher photosynthetic rate for augmented LAI was stated by Thiyagarajan et al., (2002).

\section{Crop growth rate (CGR) (Table.5)}

Crop growth rate (CGR) is a gathering of daily radiation interception, radiation use efficiency and leaf area index. Crop growth rate is representing photosynthetic efficiency of a plant, which depend upon the DMP of rice. The CGR was faster up to PI and thereafter the growth rate was rather slow. Among different irrigation management practices, continuous flooding $\left(\mathrm{A}_{3}\right)$ noticed higher CGR of 187.1 and $162.5 \mathrm{~kg} \mathrm{ha}^{-1}$ day $^{-1}$ at AT to PI and PI to harvest stage, respectively. It was statistically similar with irrigation after $10 \mathrm{~cm}$ depletion of FWT $\left(\mathrm{A}_{1}\right)$ (178.5 and $\left.156.1 \mathrm{~kg} \mathrm{ha}^{-1} \mathrm{day}^{-1}\right)$.The above ground parts of the plant are positively influenced by better root growth and due to increased leaf area, CGR was increased. These conclusions are in harmony with Okuma et al., (2011). Lesser CGR of 160.2 and $142.5 \mathrm{~kg} \mathrm{ha}^{-1} \mathrm{day}^{-1}$ was recorded under irrigation after $15 \mathrm{~cm}$ depletion of FWT $\left(\mathrm{A}_{2}\right)$ at both the stage, respectively.

Weed free check $\left(\mathrm{B}_{3}\right)$ much produced higher crop growth rate at AT to PI and PI to harvest stage $\left(211.9\right.$ and $190.5 \quad \mathrm{~kg} \quad \mathrm{ha}^{-1}$ day $\left.^{-1}\right)$ respectively. It was statistically comparable with PE Pyrazosulfuron ethyl @ 20g a.i. ha ${ }^{-1}$ fb POE Bispyribac sodium @ 25g a.i. ha ${ }^{-1}$ 
accounting 202.4 and $182.6 \mathrm{~kg} \mathrm{ha}^{-1} \mathrm{day}^{-1}$. Next to these treatments, application of $\mathrm{PE}$ Bensulfuron methyl + Pretilachlor @ $0.6 \mathrm{~kg}$ a.i. $\mathrm{ha}^{-1} \mathrm{fb}$ POE Bispyribac sodium @ 25g a.i. $\mathrm{ha}^{-1}$ recorded the crop growth rate values 178.6 and $167.1 \mathrm{~kg} \mathrm{ha}^{-1} \mathrm{day}^{-1}$, respectively). Whereas, unweeded control recorded lower CGR values of 108.2 and $74.5 \mathrm{~kg} \mathrm{ha}^{-1} \mathrm{day}^{-1}$ at AT to PI and PI to harvest stage.

Significant interaction between irrigation and weed management was noticed only during AT to PI stage. Continuous flooding along with weed free check $\left(\mathrm{A}_{3} \mathrm{~B}_{3}\right)$ got higher CGR of $232 \mathrm{~kg} \mathrm{ha}^{-1} \mathrm{day}^{-1}$. It was followed by continuous flooding with PE Pyrazosulfuron ethyl @ 20g a.i. ha ${ }^{-1}$ fb POE Bispyribac sodium @ 25 g a.i. ha ${ }^{-1}\left(\mathrm{~A}_{3} \mathrm{~B}_{2}\right)(213.5 \mathrm{~kg} \mathrm{ha}$ ${ }^{1}$ day $\left.^{-1}\right)$.

The same result was also corroborated with Ali et al., (2008) who detailed that more dry matter production attained by optimal irrigation resulted in more CGR due to more carbohydrate assimilation and lesser competition among the plants. Lesser CGR was observed with irrigation after $15 \mathrm{~cm}$ depletion of FWT with unweeded control $\left(\mathrm{A}_{2} \mathrm{~B}_{4}\right)$ produced $94.8 \mathrm{~kg} \mathrm{ha}^{-1}$ day $^{-1}$.

\section{Microbial Population of soil}

\section{Bacterial Population (Table 6)}

Among different irrigation management practices, soil bacterial population significantly increased under FWT method of irrigation than continuous flooding water after harvest of crop. The increasing bacterial population were dominated in order of irrigation after $10 \mathrm{~cm}$ depletion of FWT $\left(\mathrm{A}_{1}\right)$ $>$ irrigation after $15 \mathrm{~cm}$ depletion of FWT $\left(\mathrm{A}_{2}\right)$ $>$ continuous flooding $\left(\mathrm{A}_{3}\right)$. This could be attributed due to the water regimes providing favourable environment for soil microorganism.
Regarding weed management, weed free check $\left(\mathrm{B}_{3}\right)$ recorded lower bacterial population significantly over other weed control. Application of PE Pyrazosulfuron ethyl @ $20 \mathrm{~g}$ a.i. ha ${ }^{-1} \mathrm{fb}$ POE Bispyribac sodium @25 g a.i. ha ${ }^{-1}\left(\mathrm{~B}_{2}\right)$ recorded significantly higher bacterial population followed by PE Bensulfuron methyl + Pretilachlor @ $0.6 \mathrm{~kg}$ a.i. $\mathrm{ha}^{-1}\left(\mathrm{~B}_{1}\right)$ and unweeded control plots $\left(\mathrm{B}_{4}\right)$.

\section{Fungalpopulation (Table 6)}

Significantly higher fungal colonies were found under FWT method of irrigation regime than the plots under continuous flooding after crop harvest. Irrigation after $10 \mathrm{~cm}$ depletion of FWT $\left(\mathrm{A}_{1}\right)$ recorded higher fungal population followed by irrigation after $15 \mathrm{~cm}$ depletion of FWT $\left(\mathrm{A}_{2}\right)$ method of irrigation.

Unweeded control $\left(\mathrm{B}_{4}\right)$ recorded greater fungal populations significantly over other weed control. Among the herbicidal treatments, larger fungal colonies were observed in application of PE Pyrazosulfuron ethyl @20g a.i. ha ${ }^{-1}$ fb POE Bispyribac sodium @25 g a.i. ha ${ }^{-1}\left(\mathrm{~B}_{2}\right)$ and it was followed by the application of PE Bensulfuron methyl + Pretilachlor @ $0.6 \mathrm{~kg}$ a.i. ha ${ }^{-1} \mathrm{fb}$ POE Bispyribac sodium @ 25g a.i. $\mathrm{ha}^{-1}\left(\mathrm{~B}_{1}\right)$. Whereas, the least fungal population was found in weed free check $\left(B_{3}\right)$.

\section{Actinobacteria (Table 6)}

With respect to irrigation management, the soil actinobacteria population were significantly higher in continuous flooding after crop harvest than FWT method of irrigation. Comparing FWT method of irrigation, irrigation after $10 \mathrm{~cm}$ depletion of FWT $\left(\mathrm{A}_{1}\right)$ recorded higher population and it was followed by irrigation after $15 \mathrm{~cm}$ depletion of FWT $\left(\mathrm{A}_{2}\right)$. 
Significantly higher actinobacteria population was recorded under unweeded control compared to weed control treatments. These higher Actinobacteria colonies were dominated in weedy check might beduetothenon-disturbance of soil environment caused in weedy check. The results are in line with Kumar (2012).PE Pyrazosulfuron ethyl @ 20g a.i. ha ${ }^{-1}$ fb POE Bispyribac sodium@25 g a.i.ha ${ }^{-1}$ showed more actinomycetes population and it was followed by PE Bensulfuron methyl + Pretilachlor @ $0.6 \mathrm{~kg}$ a.i. ha ${ }^{-1}$ fb POE Bispyribac sodium @25g a.i. ha ${ }^{-1}\left(\mathrm{~B}_{1}\right)$. While, the least antinobacteria population was found in weed free check $\left(\mathrm{B}_{3}\right)$.

\section{Grain and straw yield (Table 7)}

Grain and straw yield are the key parameters of any crop, which was reflected by the impact of crop growth parameters and yield contributing characters that are affected by various management option.

The rice grain and straw yield was greatly influenced by irrigation management treatments. Among, continuous flooding $\left(\mathrm{A}_{3}\right)$ recorded higher grain and straw yield of 6222 \& $7127 \mathrm{~kg} \mathrm{ha}^{-1}$. This could be attributed due to taller plants and in turn more drymatter accumulation under continuous flooding. However, the harvest index was not affected by different irrigation regimes. These results are in agreement with Son et al., (2008). But the equivalent yield was observed with irrigation after $10 \mathrm{~cm}$ depletion of FWT $\left(\mathrm{A}_{1}\right)$ produced $5851 \& 6748 \mathrm{~kg}$ of grain and straw yield ha ${ }^{-1}$. The lower yield of $5173 \& 6127 \mathrm{~kg}$ $\mathrm{ha}^{-1}$ was noticed with irrigation after $15 \mathrm{~cm}$ depletion of FWT $\left(\mathrm{A}_{2}\right)$.

Imposing of different weed management, weed free check $\left(\mathrm{B}_{3}\right)$ significantly produced maximum grain and straw yield of 6753 \& $7568 \mathrm{~kg} \mathrm{ha}^{-1}$. It was identical with the application of PE Pyrazosulfuron ethyl @ 20g a.i. ha ${ }^{-1} \mathrm{fb}$ POE Bispyribac sodium @ $25 \mathrm{~g}$ a.i. $\mathrm{ha}^{-1}\left(\mathrm{~B}_{2}\right)\left(6478 \& 7381 \mathrm{~kg} \mathrm{ha}^{-1}\right)$. It was due to considerable improvement of all attributed yield attributing characters and also by reducing the crop-weed competition. Close accordance with Kumar et al., (2014).The unweeded These outcomes are in check $\left(\mathrm{B}_{4}\right)$ resulted in lowest grain and straw yield of $3808 \& 4897 \mathrm{~kg} \mathrm{ha}^{-1}$.

Among the different irrigation and weed management combinations, continuous flooding with weed free check $\left(\mathrm{A}_{3} \mathrm{~B}_{3}\right)$, registered more grain and straw yield of 6882 $\& 7675 \mathrm{~kg} \mathrm{ha}^{-1}$. However, it was statistically equivalent with $10 \mathrm{~cm}$ depletion of FWT $\left(\mathrm{A}_{1}\right)$ + PE Pyrazosulfuron ethyl @ 20g a.i. ha ${ }^{-1} \mathrm{fb}$ POE Bispyribac sodium @ $25 \mathrm{~g}$ a.i. ha ${ }^{1}\left(\mathrm{~A}_{1} \mathrm{~B}_{2}\right)$ and continuous flooding with $\mathrm{PE}$ Pyrazosulfuron ethyl @ 20g a.i. ha ${ }^{-1}$ fb POE Bispyribac sodium @ $25 \mathrm{~g}$ a.i.ha ${ }^{-1}\left(\mathrm{~A}_{3} \mathrm{~B}_{2}\right)$.The results are in line with the findings of Uphoff (2006) who found that the higher grain and straw yields ultimately attributed to the series of repeated wetting and drying were effect on beneficial increase of nutrient availability leading to better growth and development of the crop. Irrigation after $15 \mathrm{~cm}$ depletion of FWT coupled with unweeded control $\left(\mathrm{A}_{2} \mathrm{~B}_{4}\right)$ significantly found lower grain and straw yield of $2968 \& 4177 \mathrm{~kg} \mathrm{ha}^{-1}$.

\section{References}

Ali, Muhammad Aslam, Ju Hwan Oh, and Pil Joo Kim. 2008. Evaluation of silicate iron slag amendment on reducing methane emission from flood water rice farming. Agriculture, ecosystems \& environment. 128 (1-2):21-26.

Bhan, V. M., 1981. Effects of hydrology, soil moisture regime, and fertility management on weed populations and their control in rice. $\mathrm{p} 48-56$.

Chowdhury, Md R., Vinod Kumar, Abdus 
Sattar, and Koushik Brahmachari. 2014. Studies on the water use efficiency and nutrient uptake by rice under system of intensification. The Bioscan. 9 (1):8588.

Janiya, J. D., and Moody, K. 1982. Weed control in transplanted rice (Oryza sativa L.) grown under different moisture regimes.Philippine Journal Weed Science. 9:29-35.

Kabir, M. H., M. N. Bari, M. Moynul Haque, G. J. U. Ahmed, and Islam, J. M. S. 2008. Effect of water management and weed control treatments on the performance of transplanted aman rice.Bangladesh Journal of Agricultural Research. 33 (3): 399-408.

Kulkarni, Suresh. 2011. Innovative technologies for water saving in irrigated agriculture. International journal of water resources and arid environments. 1 (3):226-231.

Kumar, Amit. 2012. Integrated Weed Management in Rice (Oryza sativa L.) grown by system of rice intensification method.management challenge. Vol. 60: IWMI.

Kumar, D. P., Naresh, Nandal, and Punia, S. S. 2014. Efficacy of post-emergence herbicides for weed control in transplanted rice.Indian Journal of Weed Science. 46 (4): 380-382.

Kunnathadi, Musthafa, C. T. Abraham, C. George Thomas, and Girija, T. 2015. Comparative evaluation of SRI with conventional system in the irrigated rice tracts of Kerala. Journal of Tropical Agriculture. 53 (1):8-16.

Maragatham, N., and James Martin, G. 2010. Effect of land configuration techniques, NP levels and bioinoculants on soil available nutrients and soil microorganism in aerobic rice production in South India.Experimental Agriculture. 43 (4):463-476.

Okuma, Eiji, Md Sarwar Jahan, Shintaro
Munemasa, Mohammad Anowar Hossain, Daichi Muroyama, Mohammad Mahbub Islam, Ken'ichi Ogawa, Megumi Watanabe-Sugimoto, Yoshimasa Nakamura, and Yasuaki Shimoishi. 2011. Negative regulation of abscisic acid-induced stomatal closure by glutathione in Arabidopsis.Journal of plant physiology. 168 (17):2048-2055.

Oliver, M. M. H., M. S. U. Talukder, and Ahmed, M. 2008. Alternate wetting and drying irrigation for rice cultivation.Journal of the Bangladesh Agricultural University. 6 (2):409-414.

Patra, A. K., J. Halder, and Mishra,M. M. 2011. Chemical weed control in transplanted rice in Hirakud command area of Orissa. Indian Journal of Weed Science. 43 (3and4):175-177.

Saha, Sanjoy, and Rao, K. S. 2009. Efficacy of sulfonylurea herbicides for broadspectrum weed control in wet directsown summer rice.ORYZA-An International Journal on Rice. 46 (2):116-119.

Santheepan, S., and Ramanathan, S. P.2016. Investigation on AWDI method with field watertube for rice production under SRI.Int. J. Agric. Sci. Res. 6 (3): 117-124.

Satyanarayana Reddy, G., M. Prem Sekhar, C. N. Chandrasekhar, and Muthukrishnan, P. 2013. Effect of crop establishment methods and weed management practices on productivity and economics of wet seeded rice. Indian Journal of Agricultural Research.47 (5).

Shekhar, J., B. S. Mankotia, and Bindra, A. D. 2004. Bio-efficacy of Some New Herbicides against Weedin Transplanted Rice (Oryza sativa L.).Indian Journal of Weed Science. 36 (1 and2):50-53.

Singh, Vijay, Mangi L. Jat, Zahoor A. Ganie, Bhagirath S. Chauhan, and Raj K. 
Gupta. 2016. Herbicide options for effective weed management in dry direct-seeded rice under scented ricewheat rotation of western Indo-Gangetic Plains.Crop Protection. 81:168-176.

Smith, J.Roy and Fox, W. T. 1973.Soil water and growth of rice and weeds. Weed Science. 21 (1):61-63.

Son, Ngo Thanh, Rodrigo B. Badayos, Pearl B. Sanchez, Pompe C. Sta Cruz, Nguyen Van Dung, and Nguyen Huu Thanh. 2008. Water productivity and soil chemical properties under varying water regimes on spring rice (Oryza sativa L.) in Hanoi, Vietnam. Philippine Journal of Crop Science. 33 (3):56-70.

Subramanian, E., S. N. M. Boopathi andBalasubramanian, R. 2002.Studies on the effect of weed management practices on weed control in drum seeded wet rice.Indian Journal of Weed Science. 34 (3and4):201-203.

Thakur, K.Amod, Sreelata Rath, S. Roychowdhury and Norman Uphoff. 2010. Comparative performance of rice with system of rice intensification (SRI) and conventional management using different plant spacings.Journal of Agronomy and Crop Science. 196
(2):146-159.

Thiyagarajan, T. M., V. Velu, S. Ramasamy, D. Durgadevi, K. Govindarajan, R. Priyadarshini, C. Sudhalakshmi, K. Senthilkumar, P. T. Nisha, and Gayathry, G. 2002. Effects of SRI practices on hybrid rice performance in Tamil Nadu, India.Water-Wise rice production. 8-11.

Uphoff, Norman. 2006. The system of rice intensification (SRI) as a methodology for reducing water requirements in irrigated rice production.International Dialogue on Rice and Water: Exploring Options for Food Security and Sustainable Environments:1-23.

Walia, U. S., S. S. Walia, Amandeep Singh Sidhu and Shelly Nayyar. 2012. Bioefficacy of pre-and post-emergence herbicides in direct-seeded rice in Central Punjab.Indian Journal of Weed Science. 44 (1):30-33.

Zhang, Hao, Yaguang Xue, Zhiqin Wang, Jianchnag Yang, and Jianhua Zhang. 2009. An alternate wetting and moderate soil drying regime improves root and shoot growth in rice.Crop Science. 49 (6):2246-2260.

\section{How to cite this article:}

Mohanapriya, R. and Vijay Aravinth, K. 2021. Investigation on Field Water Tube and Low Dose Herbicides on Growth Parameters, Microbial Population and Yield of Transplanted Rice (Oryza sativa L.). Int.J.Curr.Microbiol.App.Sci. 10(01): 3513-3524.

doi: https://doi.org/10.20546/ijcmas.2021.1001.415 